\title{
Assessment of Periwinkle (Tympanotonus fuscatus) Found in Crude Oil and Non Crude Oil Contaminated Areas of Rivers State, Nigeria
}

\author{
Nwankwo Christiana Chika, Nlemanya Chioma Mercy \\ School of Science Laboratory Technology, University of Port Harcourt, Port Harcourt, Rivers State, Nigeria
}

Email address:

conwankwo2007@gmail.com (N. C. Chika)

\section{To cite this article:}

Nwankwo Christiana Chika, Nlemanya Chioma Mercy. Assessment of Periwinkle (Tympanotonus fuscatus) Found in Crude Oil and Non Crude Oil Contaminated Areas of Rivers State, Nigeria. Journal of Health and Environmental Research. Vol. 5, No. 2, 2019 , pp. 32-40. doi: $10.11648 /$ j.jher.20190502.11

Received: February 25, 2019; Accepted: April 4, 2019; Published: April 26, 2019

\begin{abstract}
The assessment of periwinkles (Tympanotonus fuscatus) found in crude oil and non-crude oil contaminated area of Rivers State evaluates the physiochemical (Heavy metal, proximate analysis and total petroleum hydrocarbon) and microbial quality of periwinkle samples. The results obtained showed mean Total Petroleum Hydrocarbon values were $0.149999 \mathrm{mg} / \mathrm{kg}$, $0.314500 \mathrm{mg} / \mathrm{kg}, 0.709996 \mathrm{mg} / \mathrm{kg}$ and $0.16398 \mathrm{mg} / \mathrm{kg}$, in Bodo, Cawthorne channel, Okrika and Emohua (control) samples respectively. Heavy metals in contaminated and non-contaminated samples ranged from $10.05-22.00 \mathrm{mg} / \mathrm{kg} \operatorname{Iron}(\mathrm{Fe}), 0.25-$ $1.05 \mathrm{mg} / \mathrm{kg}$ Zinc (Zn), 0.06-0.23 mg/kg Nickel (Ni), 0.001-0.034 mg/kg Chromium (Cr), 0.003-0.02 mg/kg Cadmium (Cd), 0.0001-0.007 mg/kg Lead (Pb), 2.01-4.02 mg/kg Manganese $(\mathrm{Mn})$ and $1.05-1.97 \mathrm{mg} / \mathrm{kg}$ Copper $(\mathrm{Cu})$. The proximate analysis revealed protein, moisture, fiber, ash, lipid and carbohydrate contents of all samples ranged from $23.6-30.2 \%, 49.0-60.4 \%$, $2.5-12.3 \%, 5.0-7.2 \%, 1.4-3.4 \%$ and $2.5 \%$ respectively. Total bacterial count, ranged from $5.75 \times 10^{3}-2.37 \times 10^{6} \mathrm{cfu} / \mathrm{g}$ in Raw and $2.02 \times 10^{3}-1.49 \times 10^{6} \mathrm{cfu} / \mathrm{g}$ in Boiled samples, while the total fungal count ranged from $2.05-3.88 \times 10^{3} \mathrm{cfu} / \mathrm{g}$ and $1.42-2.0 \times 10^{3}$ $\mathrm{cfu} / \mathrm{g}$ in the Raw and Boiled samples respectively. There was a statistically significant difference in microbial counts between the Raw and Boiled samples from the contaminated sites when compared to the non-contaminated site as $\mathrm{p}<0.05$. The organisms isolated in the study were Bacillus sp, Pseudomonas sp, Staphylococcus sp, Enterobacter sp, Citrobacter sp, Salmonella sp, Shigella sp, Proteus sp, Micrococcus sp, E. coli, Aspergillius sp, Fusarium sp, Saccharomyces sp and Penicillium sp. Periwinkles though, nutritionally valuable had higher microbial load and harbored pathogenic microorganisms which could cause health effect if not properly cooked, the source of periwinkles should be monitored as increase in heavy metal content has toxic effect on health.
\end{abstract}

Keywords: Crude Oil, Tympanotonus fuscatus, Microorganisms, Proximate Analysis

\section{Introduction}

In Nigeria today marine environment had been contaminated due to the spill of crude oil which is a complex mixture of many chemical compounds composed primarily of phenol, an aromatic hydrocarbons (PAHs) which include monocyclic (MAH) and polycyclic (PAHs) hydrocarbon compound. These at appropriate concentrations are of toxicological interest towards living systems [1-2]. These PAHs can originate from anthropogenic or biogenic sources. As a result of their hydrophobicity, low water solubility and vapor pressure, occurrence of PAHs in the environment is of concern due to the carcinogenic properties and their ability to exert toxic effects through the aryl hydrocarbon receptor (AHR) medicated mechanism, similar to dioxins [3-4].

Mangrove are swampy areas for fish and nurseries for juvenile fish and the extensive pollution of these areas impact on sea foods, apart from direct absorption from the water when oil spill, marine species such as fishes and shell fishes like the crustaceans and mollusk (Periwinkle) whose survival depends on the water body may be contaminated.

Periwinkle (Tympanococus fuscatus) is a common seafood worldwide around seashores. They are invertebrates and herbivorous. Periwinkle consists of two (2) general 
Tympanococus and Pachymelania. The most common periwinkle found in Nigeria is the tropical periwinkle (Tympanotonus fuscatus) which is of two (2) varieties Tympanotonus fuscatus var fuscatus which has spine on its shell and Tympanococus fuscatus var radullar which has a smooth or granular shell. They both can exist within the same ecosystem but one variety is usually dominant in the ecosystem. They are about $4.5-5 \mathrm{~cm}$ in length usually dark brown or black and has a solid spiral (turbinate) shell [5]. Periwinkles (Tympanococus fuscatus) are commonly abundant in mangrove mud flat [6]. The periwinkle Tympanotonus fuscatus is edible and the brackish water specie is common to the Niger Delta region of Nigeria. It is locally known as "ISAM" or "PIOM PIOM" to the people of Niger Delta, and serves as good delicacy in soups.

Sea foods have high nutritive base and serve as a good medium for the growth of microorganisms leading to food poisoning (Cholera and Salmonellosis) when consumed [7]. The most prevalent microorganisms that contaminate sea food are bacteria and fungi. Pollution of water bodies introduce pathogenic organisms into the ecosystem where these sea foods are harvested. They may contain high numbers of coliform and these organisms would also be present in sea foods harvested from such water system. Most times, the concentration of pathogenic microorganisms and toxic materials that accumulate in sea food are from untreated human waste and waste water from industries introduced into the water bodies inhabited by these periwinkles (Tympanococus fuscatus). [5] reported that shell fishes are able to harbor and bio magnify microorganisms in their environment. The aim of this research is to evaluate the quality (microbial, heavy metal and nutritional) of periwinkle samples found in some parts of River state, Niger Delta.

\section{Materials and Method}

\subsection{Sampling Site/Collection}

Periwinkle samples (Tympanotonus fuscatus) used for the study were randomly handpicked from four (4) creeks at different areas in River State, Niger Delta region of Nigeria. The sampling sites were three (3) crude oil contaminated and one (1) non crude oil contaminated site for control. The samples were collected from Oba-Ama in Okirika, Cawthorne channel in Kalabari, Bodo west in Ogoni and control sample was collected from Elibrada in Emuoha all in River State of Nigeria. The samples were put into well labeled perforated plastic containers and brought to the laboratory.

The samples brought to the laboratory were divided into two (2) halves for microbial evaluation and physio-chemical analysis.

\subsection{Materials/Equipment}

Different equipment/materials and methods were used in the course of the study in order to evaluate the physiochemical analysis (Heavy metal concentration and Total
Petroleum Hydrocarbon level (TPH) and Proximate analysis of the periwinkle) and microbiological analysis (microbial quality).

\subsection{Physio-Chemical Analysis}

\subsubsection{Heavy Metals}

Heavy metals were analyzed using the Atomic Absorption spectrophotometer method (AAS).

1) Periwinkle samples were digested by dry ash method

2) Ash was dissolved with 6 drops of concentrated Hydrochloric acid (HCL).

3) Made up with $50 \mathrm{ml}$ capacity with distilled water

4) The digest was underline with AAS according to the instrument procedure.

\subsubsection{Total Petroleum Hydrocarbon Analysis (TPH)}

The TPH Level of the periwinkle samples were analyzed by Gas Chromatography (GC) method.

\subsubsection{Proximate Analysis}

\section{a. Protein}

Protein content was analyzed by Kjeldahl method in three different stages

Stage 1 Digestion

$0.1 \mathrm{~g}$ of periwinkle sample was digested with 3 grams of digestion catalyst in a clean $250 \mathrm{ml}$ conical flask, $20 \mathrm{ml}$ of concentrated sulphuric acid was also added to the sample and heated to digest.

Stage 2 Distillation

Twenty (20) $\mathrm{ml}$ of the diluted digest was measured into a distillation flask, the flask was held in place on the electro thermal heater or hot plate. The distillation flask was attached a liebig condenser connected to a receiver containing $10 \mathrm{ml}$ of $2 \%$ boric acid indicator, $40 \mathrm{ml}$ of $40 \%$ sodium hydroxide was injected into the digest via a syringe attached to the mono-arm steelhead until the digest became strongly alkaline. The mixture was heated to boiling and the distilled ammonia gas via the condenser into the receiver beaker, the color of the boric acid changed from purple to greenish as ammonia distillate was introduced into the boric acid.

Stage 3 Titration

The distillate was titrated with standard $0.1 \mathrm{~N}$ hydrochloric acid solution back to purple from greenish and the volume of hydrochloric acid added to effect this change was recorded as titer value.

\section{b. Carbohydrate}

Carbohydrate content was analyzed by Clegg Anthrone method

$0.1 \mathrm{~g}$ of the sample was weighed into a $25 \mathrm{ml}$ volumetric flask. $1 \mathrm{ml}$ distilled water and $1.3 \mathrm{ml}$ of $62 \%$ pentatonic acid was added and shaked for 20 mins to homogenize completely. The flask was made up to $25 \mathrm{ml}$ mark with distilled water and stopper. The solution was filtered through a glass filter paper or allowed to sediment and decanted, $1 \mathrm{ml}$ of the filtrate was collected and transferred into a $10 \mathrm{ml}$ test tube this was diluted to volume with distilled water. One $(1 \mathrm{ml})$ of working solution was pipette into a clean test tube 
and $5 \mathrm{ml}$ Anthrone reagent was added, thereafter, $1 \mathrm{ml}$ distilled water and $5 \mathrm{ml}$ Antrone reagent was mixed. The whole mixture were read at $630 \mathrm{~nm}$ wave length using the $1 \mathrm{ml}$ distilled water and the $5 \mathrm{ml}$ Anthrone reagent prepared as blank solution, glucose of $0.1 \mathrm{ml}$ was also prepared and treated as the sample with Anthrone reagent, absorbance of the standard glucose was read and the values of carbohydrate and glucose were calculated.

\section{c. Moisture}

Moisture content was analyzed by air oven method

One (1) gram of periwinkle sample was weighed into a clean dried porcelain evaporating dish and placed in an oven to maintain a temperature of $105^{\circ} \mathrm{C}$ for six hours. The dish was cooled in desiccators to room temperatures, it was reweighed and recorded.

\section{d. Lipid}

Lipid content was analyzed by Soxhlet extraction method

Two (2) grams of periwinkle sample was inserted into a filter paper and placed into a soxhlet extractor. The extractor was placed into a pre-weighed dried distilled flask, the solvent (acetone) was introduced into the distillation flask via the condenser and attached to the soxhlet extractor. The setup was held in place with a retort stand clamp, cooled water jet was allowed to flow into the condenser and the heated solvent was refluxed as a result. The lipid in the solvent chamber was extracted in the process of continuous refluxing, when the lipid was observably extracted completely from the sample under test, the condenser and the extractor were disconnected and the solvent was evaporated to concentrate the lipid. The flask was dried in the air oven, weighed and re-weighed to obtain the weight of lipid.

\section{e. Ash}

Ash content was analyzed by law and ignition method

One (1) gram of the periwinkle sample was weighed into porcelain crucible which was previously preheated and weighed, the crucible was inserted into a muffle furnace and regulated to a temperature of $630^{\circ} \mathrm{C}$ for three hours and allowed to cool to room temperature and re-weighed.

\subsection{Isolation of Microorganisms}

The second half of the periwinkle samples were analyzed microbiologically for total heterotrophic bacteria count (THBC), Total heterotrophic Fungi Count, (THFC), Bacterial (HUB), Hydrocarbon Utilizing Fungi Count (HUF) and other pathogenic microorganisms..

\subsubsection{Sample Preparation}

The periwinkle samples for microbiological analysis were processed by washing properly with clean water and divided into two (2). One (1) part was parboiled for 10 minutes and the other part cracked aseptically to separate the soft tissues from the shell with a sterile needle and put into beakers.

Pre-enriched medium was prepared by dissolving with normal saline and samples were transferred and homogenized using a stomacher.

\subsubsection{Media Preparation}

1) Salmonella Shigella Agar (SSA): A selective medium used for identifying Salmonella and Shigella was prepared. 63 grams of powder was dissolved in 1 litre of distilled water in a conical flask and boiled according to manufacturer's instruction.

2) Eosine Mythelene Blue Agar EMB): A selective media used for the identification of Eschericia coli, 37.5 grams of powder was dissolved in 1 litre of distillated water in council flask.

3) Nutrient Agar (NA): An all-purpose media. 28 grams of powder was dissolved in 1litre of distilled water in a conical flask.

4) Potato Dextrose Agar (PDA): A selective media used for identifying fungi, 39 grams of powder was dissolved in 1 litre of distilled water in a conical flask.

5) Mineral Salt Agar (MSA): A selective medium to isolate microorganisms that utilize hydrocarbon as a carbon source, 0.42 grams of $\mathrm{MgSo}_{4}, 0.29$ grams of $\mathrm{Kcl}, 1.25$ grams of $\mathrm{K}_{2} \mathrm{HO}_{4}, 0.83$ grams of $\mathrm{KH}_{2} \mathrm{PO}_{4}, 0.83$ grams of $\mathrm{NH}_{4} \mathrm{NO}_{3}$ gram 10.0 grams of $\mathrm{Nacl}$ and 15.0 grams of agar were dissolved in 1 litre of distilled water in a conical flask.

\subsubsection{Sterilization}

All material (media, filter paper and glass wares like Petridish and pipettes) used in the study were sterilized by autoclaving at $120^{\circ} \mathrm{C}$ for 15 minutes. Thereafter materials were removed from the autoclave and kept on a properly disinfected work bench. Media were allowed to cool to about $45^{\circ} \mathrm{C}$ before pouring into the Petri-dish aseptically.

\subsubsection{Serial Dilution}

Serial dilution of samples was done to achieve a reduction in the microbial population in the sample, ten (10) grams of sample was weighted into $90 \mathrm{ml}$ of peptone water and homogenized using a stomacher thereafter, $1 \mathrm{ml}$ was taken and transferred into test tube containing $9 \mathrm{ml}$ of sterile diluent (peptone water) to make dilution using a sterile pipette under aseptic condition.

\subsubsection{Enumeration and Characterization of Bacteria}

A sterile pipette was used to transfer $0.1 \mathrm{ml}$ of homogenized inoculum from dilution test tube into duplicate plates of pre-dried nutrient agar (NA), Salmonella Shigella (SSA) and Eosine mythelene Blue (EMB) Agar plates. Spread plate technique was employed, hockey stick was dipped into ethanol, passed through a bunsen flame and used to spread the inoculum evenly on the agar surface. All inoculations were done aseptically, thereafter, plates were incubated at $37^{\circ} \mathrm{C}$ for $24 \mathrm{hrs}$. Distinct colonies were counted to obtain colony forming unit (CFU) per gram of samples.

\subsubsection{Enumeration and Characterization of Total Heterotrophic Fungi (THF)}

After media preparation and sterilization, plates were allowed to cool to about $45^{\circ} \mathrm{C}, 0.1 \%$ of lactic acid was incorporated into the already prepared media (Potato 
Dextrose Agar) and poured aseptically into sterile petridishes, $0.1 \mathrm{ml}$ of homogenized inoculum from dilution was transferred into agar surface using a sterile pipette and was spread evenly and aseptically using spread plate technique. The plates were incubated at ambient room temperature $\left(25 \pm 2^{\circ} \mathrm{C}\right)$ for $72-120 \mathrm{hrs}$ to obtain colony forming unit (CFU) per gram of samples.

\subsubsection{Enumeration and Characterization of Hydrocarbon Utilizing Bacteria (HUB) and Hydrocarbon Utilizing Fungi (HUF) \\ HUB}

Vapor - phase transfer method was adopted to estimate the population of HUB.

Mineral salt agar was compounded, media prepared and $0.1 \mathrm{ml}$ of a homogenized inoculum was collected using a sterile pipette from serially diluted samples and transferred onto the surface of duplicate plates of pre-dried mineral salt Agar (MSA). The spread plate technique was employed and the inoculum was spread evenly on the agar surface thereafter, sterile filter paper (Whatman No 1) was soaked with crude oil, picked with sterile forceps and placed on the lid of the petri-dish, the plates were incubated in an inverted position at ambient room temperature $\left(25 \pm 2^{\circ} \mathrm{C}\right)$ for $72-120$ hrs. Distinct colonies that developed were counted to obtained colony forming unit (cfu) per gram of samples.

HUF

After media preparation and sterilization, media was allowed to cool to about $45^{\circ} \mathrm{C}$, antibiotics was incorporated into the already prepared media and poured into sterile petridishes, the procedure above for HUB was also followed.

\subsubsection{Sub-Culturing and Purification of Isolates}

A loopful of distinct colonies which grew on the different media plates, were pick out with a sterile wire-loop 'based on cultural characteristics (color, shape, size, elevation, margin, opacity and appearance) and transferred to the edge of a freshly prepared nutrient agar plate and streaked out over the surface of the medium in one of several patterns. The streaking was done by heating the wire loop to red-hot at intervals streaked places were incubated at $37^{\circ} \mathrm{C}$ for $24 \mathrm{hrs}$, thereafter, distinct colonies that developed from the streaked plates were transferred on agar slant and incubated at $37^{\circ} \mathrm{C}$ for 24 hrs to obtain stock culture.

\subsection{Gram Staining}

The gram's staining technique was carried out to differentiate the isolates into gram positive or gram negative bacteria based on their cell wall composition. A smear was prepared from a $24 \mathrm{hr}$ fresh culture and heat-fixed by passing over a flame and subsequently, the smear was flooded with crystal violet for 1 minute and rinsed under slow flowing tap, again, the smear was flooded with gram's iodine for 1 minute and rinsed under a slow flowing tap. The slides were allowed to air dry and viewed under the light microscope using oil immersion objective lens, cells that appeared purple were recorded as gram-positive cells while cells that appeared pink under the microscope were recorded as gram-negative cells.

\subsection{Spore Test}

This test was carried out to detect the presence of spore or the possession of spores by a bacterial isolate. The bacterial culture was smeared and heat fixed on a clean-grease free glass slide. The slide was covered with filter paper and flooded with $1 \%$ malachite green reagent.

The slide was heated for 3-5 minutes over boiling water for the reagent to penetrate into the cells of bacteria, the slide was gently rinsed under a flowing tap, counter stained with safranin reagent and allowed to air dry, spores stained green while vegetative cells strained red when viewed under the microscope,

\subsection{Biochemical Tests}

\subsubsection{Catalase Tests}

This test determined the ability of an organism to breakdown hydrogen peroxide $\left(\mathrm{H}_{2} \mathrm{O}_{2}\right)$ into oxygen and water. Only organisms that have the enzyme catalase are able to catalyze the reaction. The presence of the enzyme in a bacterial cell is evident when a small inoculum was introduced into a 3\% hydrogen peroxide solution and rapid production of effervescence occurs and the absence of catalase is evident by a lack of or weak production of effervesce.

\subsubsection{Citrate Test}

The test was carried out to determine the ability of an organism to utilize sodium citrate as its sole source of carbon and inorganic ammonium salt as its only source of nitrogen. Bacteria that can grow on this medium turn the bromothymol blue indicator from green to blue. Simmon citrate agar was prepared in a capped tube according to manufactures instruction, a sterile wire loop was used to pick a loopful of the test organism and streaked on slant surface the tube it was incubated at $37^{\circ} \mathrm{C}$ for $48 \mathrm{hrs}$ and a change in color from green to blue was indicative of a negatives result.

\subsubsection{Indole Test}

The test determined the ability of an organism to split the amino acid tryptophan to form pyruvic acid, ammonia and indole using the enzyme tryptophanase. A loopful of test organism was inoculated into sterile peptone water medium and incubated at $37^{\circ} \mathrm{C}$ for $45 \mathrm{hrs}$, thereafter, $0.3-0.5 \mathrm{ml}$ of Kovac's reagent was added using a pasteur pipette appearance of red ring layer on medium was indicative of positive indole test while development of a yellow ring was indicative of negative result.

\subsubsection{Methyl Red/Vogues Proskaver (MR-VP) Test}

This test was carried out to determine the ability of an organism to produce and maintain stable acid and product from glucose fermentation and to determine the ability of some organisms to produce neutral end products such as acetyl-methyl, carbonyl or acetone from glucose fermentation. The MR-VP broth medium is used for this test. 
A loopful of test organism inoculated into $10 \mathrm{ml}$ sterile MR-VP broth medium prepared according to manufacturer's instruction and incubated at $35-37^{\circ} \mathrm{C}$ for $48 \mathrm{hrs}$, after incubation, the broth culture was shared into two equal parts $(5 \mathrm{ml})$. One part was used for methyl red (MR) test and the other part for Vogues Proskauer (VP) test, to the part for MR, 5-6 drops of methyl red reagent was added and to the part for VP, $0.36 \mathrm{ml}$ (6 drops) of 5\% alpha-naphthol and $0.3 \mathrm{ml} \mathrm{(3}$ drops) of $40 \% \mathrm{KOH}$ reagent were added and the development of red coloration is indicative of positive MRVP test.

\subsubsection{Motility Test}

This test was carried out to determine if an organism is motile, an organism must possess flagella (locomotory organelle) to be motile. Semi-solid nutrient agar was used for this test, half strength of the medium was prepared following manufacturer's instruction and a young (fresh) colony was picked with a sterile loop and inoculated by stabbing into the medium, the tube was incubated at $37^{\circ} \mathrm{C}$ for $24-48 \mathrm{hrs}$. Growth (in diffused form) from line of stab into the medium was indicative of positive result whereas growth only along the line of stab was indicative of a negative result.

\subsubsection{Oxidase Test}

This test was used to determine the presence of bacterial cytochrome oxidase using the oxidation of the substrate tetramethyl-p-phenylenediamine dihydrochloride to indolphenol.

A filter paper soaked with $1 \%$ tetra methyl-pphenylenediamine dihydrochloride was used to perform the test. A platinum wire loop was used to pick a small portion of the test organism which was rubbed on the soaked filter paper and observed for 10 minute, purple coloration on the smeared portion indicates positive result for oxidase test while no change in color on smeared portion indicates negative oxidase test.

\subsubsection{Sugar Fermentation}

This test was carried out to determine the ability of an organism to ferment sugar to produce acid and gas. One percent $(1 \%)$ peptone broth was incorporated with $1 \%$ sugar for the test. Bromocresol purple $(0.3 \%)$ indicator was added to the sugar medium, durham's tube was introduced in the tube in an inverted position, after sterilization, a loop full of test organism was introduced into the medium using sterile wire loop. The test tubes were incubated at $35-37^{\circ} \mathrm{C}$ for 48 hrs. A change in color from purple to yellow and gas production (Emptiness in the inverted Durham's tube) constitute positive sugar fermentation, the production of acid resulted in change in color of the medium from purple to yellow while gas production was detected in the inverted durham's tube.

\subsubsection{Triple Sugar Iron Agar (TSIA) Test}

This test determined the ability of the bacterial isolates to ferment glucose and lactose or sucrose and form hydrogen sulfide $\left(\mathrm{H}_{2} \mathrm{~S}\right)$, gas and acids. The triple sugar iron agar
(TSIA) was used for this test, the slant was prepared according to manufacturer's instruction. A sterile inoculation needle was used to pick the organism, it was inoculated into the medium by stabbing the center and streaking on the surface of the agar slant. The tubes were incubated at $37^{\circ} \mathrm{C}$ for $48 \mathrm{hrs}$, a change in color of media from pink to yellow indicated acid production resulting from glucose fermentation. In addition of glucose, lactose and/or sucrose when fermented, the large amount of the fermentation products formed on the slant will neutralize the alkaline amines and render the slant acidic (yellow) while a black coloration indicated production of hydrogen sulfide $\left(\mathrm{H}_{2} \mathrm{~S}\right)$ and cracks in the medium or complete upward shift of the agar slant from bottom of the tube indicates positive gas production.

\subsubsection{Starch Hydrolysis}

This test determined the ability of an organism that possesses the enzyme amylase to hydrolyze starch. The presence of this enzyme in any bacterial isolate gives it the ability to use up the starch in the medium. The starch (1\%) was incorporated into nutrient agar medium, autoclaved at $121^{\circ} \mathrm{C}$ for 15 minutes, poured into sterile Petri-dishes, allowed is solidify and dried each test organism was streaked on the surface of agar and incubated at $37^{\circ} \mathrm{C}$ for $24 \mathrm{hrs}$ thereafter, the plates were flooded with iodine solution and positive result was shown by a clear zone around the line of streak of the organism.

\section{Result}

The result of the heavy metal assessment of periwinkle harvested from crude oil and non-crude oil contaminated areas of River State is represented in Table 1

Result obtained on heavy metal analysis ranged between $10.05 \mathrm{mg} / \mathrm{kg}-22.0 \mathrm{mg} / \mathrm{kg}$ in $\mathrm{Fe}$, while $\mathrm{Zn}$ ranged between 2.25 $\mathrm{mg} / \mathrm{kg}-5.60 \mathrm{mg} / \mathrm{kg}$, Mn ranged between $2.01 \mathrm{mg} / \mathrm{kg}-4.02$ $\mathrm{mg} / \mathrm{kg}$ and $\mathrm{Cu}$ ranged between $2.05 \mathrm{mg} / \mathrm{kg}-2.59 \mathrm{mg} / \mathrm{kg}$, while $\mathrm{Pb}, \mathrm{Cr}, \mathrm{Ni}$ and $\mathrm{Cd}$ had concentrations less than $0.1 \mathrm{mg} / \mathrm{kg}$

Result obtained on Total Petroleum Hydrocarbon on periwinkle samples from crude oil and non-crude oil contaminated areas ranged from $0.149999-0.709996 \mathrm{mg} / \mathrm{kg}$ as represented in Figure 1.

The Proximate analysis shown in Table 2 revealed the protein content in contaminated and non-contaminated samples range from $28.88 \%-30.19 \%$, moisture content range from $48.95 \%-58.08 \%$, fiber content $6.46 \%-12.25 \%$, ash content $5.0 \%-9.1 \%$, lipid $1.4 \%-3.4 \%$ and carbohydrate $2.5 \%$.

Table 3 presents the Total bacterial counts on samples at different sites. Statistical analysis of the results presented in Table 3 showed the mean bacterial count of the Raw samples range from $8100 \pm 3914 \mathrm{cfu} / \mathrm{g}$ to $3110000 \pm 194250 \mathrm{cfu} / \mathrm{g}$ while the Boiled sample ranged from $4625 \pm 1350 \mathrm{cfu} / \mathrm{g}$ to $1495000 \pm 579971 \mathrm{cfu} / \mathrm{g}$ at the contaminated and noncontaminated samples. There was a decrease in counts of organisms in the Boiled samples when compared to the Raw samples. At Emohua (control), the bacterial mean count of 
Raw samples ranged from $8350 \pm 4444 \mathrm{cfu} / \mathrm{g}$ to $2110000 \pm 194250 \mathrm{cfu} / \mathrm{g}$ while the Boiled samples ranged from $4625 \pm 1350 \mathrm{cfu} / \mathrm{g}$, there was no statistically significant difference in microbial counts between the Raw and Boiled samples as is $p>0.05$ across all culture media. The samples collected from Cawthorne channel showed the mean bacterial count of Raw samples ranged from $9475 \pm 607 \mathrm{cfu} / \mathrm{g}$ to $1912500 \pm 436606 \mathrm{cfu} / \mathrm{g}$ while the Boiled samples ranged from $4300 \pm 2054 \mathrm{cfu} / \mathrm{g}$ to $975000 \pm 720023 \mathrm{cfu} / \mathrm{g}$. There was no statistically significant difference in bacterial counts between the Raw and Boiled samples cultured in NA and EMB as $p>0.05$, however, there was statistically significant difference in bacterial counts between the Raw and Boiled samples cultured in SSA and MSA as $p<0.05$. The mean bacterial counts of samples collected from Okrika ranged from $4925 \pm 1625 \mathrm{cfu} / \mathrm{g}$ to $1850000 \pm 173205 \mathrm{cfu} / \mathrm{g}$ in the Raw samples while the mean counts in the Boiled samples ranged from $2370 \pm 1350 \mathrm{cfu} / \mathrm{g}$ to $1095000 \pm 536935 \mathrm{cfu} / \mathrm{g}$, however, there was statistically significant difference in bacterial counts between the Raw and Boiled samples in all culture media as $\mathrm{p}<0.05$ except EMB. The samples collected from Bodo showed the mean bacterial count of Raw samples ranged from $6125 \pm 853 \mathrm{cfu} / \mathrm{g}$ to $23725 \pm 352644 \mathrm{cfu} / \mathrm{g}$ while the Boiled samples ranged from $2022 \pm 1052 \mathrm{cfu} / \mathrm{g}$ to $1410000 \pm 378241$. There was a statistically significant difference in bacterial counts between the Raw and Boiled samples across all culture media used as $p<0.05$. The mean THF count of Raw samples ranged from $2050 \pm 443$ to $3895 \pm 928$ while the Boiled samples ranged from $1420 \pm 658$ to $2000 \pm 244 \mathrm{cfu} / \mathrm{g}$. There was a statistically significant difference in THF counts between the Raw and Boiled samples across all sample sites as $p<0.05$. The mean HUF count of Raw samples ranged from $2075 \pm 95$ to $3300 \pm 1435$ $\mathrm{cfu} / \mathrm{g}$ while, the Boiled samples ranged from $1275 \pm 427$ to $1975 \pm 505 \mathrm{cfu} / \mathrm{g}$, there was statistically significant difference in HUF counts between the Raw and Boiled samples across the contaminated sample sites as $\mathrm{p}<0.05$, while there was no statistically significant difference in Emohua (control) sample site as $\mathrm{p}>0.05$.

With the t-test of significance, statistically significant differences were observed in the mean bacterial counts on SSA $(p=0.004)$ and EMB $(p=0.010)$ in the Raw samples between the non-contaminated. A similar effect was observed in the SSA $(p=0.013)$ in the Boiled samples, on the other hand, no statistically significant difference was observed in the THF and HUF counts between the Raw and Boiled noncontaminated and contaminated samples. Holistically, statistically significant differences were observed in the Raw $(\mathrm{p}<0.0001)$ and Boiled $(\mathrm{p}<0.0001)$ samples between the non-contaminated and contaminated soils.

Periwinkle harbored some enteric pathogenic bacteria as presented in Figure 3, the microbial isolates identified were: Bacillus sp, Pseudomonas sp, Micrococcus sp, Citrobacter $\mathrm{sp}$, Enterobacter sp, Salmonella sp, Shigella sp, Proteus sp, Staphylococcus sp, E.coli, while the fungal cultures identified in the study were Aspergillus sp, Fusarium sp, Penicillum sp and Sachromyces sp. The prevalence of these microorganisms is presented in Figures 2 and 3.

Table 1. Shows Data Obtained On Heavy Metal Analysis.

\begin{tabular}{|c|c|c|c|c|c|c|c|c|}
\hline Sample code & Fe mg/kg & Zn mg/kg & $\mathrm{Ni} \mathrm{mg/kg}$ & $\mathrm{Cr} \mathrm{mg} / \mathrm{kg}$ & $\mathrm{Cd} \mathrm{mg/kg}$ & $\mathrm{Pb} \mathrm{mg} / \mathrm{kg}$ & Mn mg/kg & $\mathrm{Cu} \mathrm{mg/kg}$ \\
\hline Em-Control & 22.0 & 5.6 & 0.023 & 0.003 & 0.02 & 0.007 & $4 . .02$ & 1.59 \\
\hline $\mathrm{CC}$ & 14.05 & 2.25 & 0.012 & 0.001 & 0.011 & 0.0001 & 3.89 & 1.47 \\
\hline $\mathrm{Ok}$ & 7.65 & 4.87 & 0.06 & 0.034 & 0.008 & 0.006 & 2.46 & 1.97 \\
\hline $\mathrm{BD}$ & 10.05 & 5.05 & 0.08 & 0.022 & 0.003 & 0.007 & 2.01 & 1.05 \\
\hline FAO/FEPA $2003(\mathrm{mg} / \mathrm{kg})$ & 0.8 & $0.3-1$ & $0.5-0.6$ & - & 2.0 & 0.3 & - & 0.5 \\
\hline FAO/WHO $2011(\mathrm{mg} / \mathrm{kg})$ & 100 & - & & - & 2.0 & 2.0 & 1.00 & 3.00 \\
\hline
\end{tabular}

FAO/FEPA [8] and FAO/WHO [9].

Key: Em- Samples collected from Emohua (Control).

CC- Samples collected from Cawthorne channel.

Ok- Samples collected from Okrika.

BD-Samples collected from Bodo Community.

Table 2. Proximate Analysis.

\begin{tabular}{lllllll}
\hline Sample code & Protein\% & Moisture\% & Fibre\% & Ash\% & Lipid\% \\
\hline Em-Control & 23.6 & 60.4 & 5.1 & 5.0 & 3.4 & 1.6 \\
CC & 29.3 & 57.6 & 6.5 & 5.0 & 1.5 & 1.4 \\
OK & 30.2 & 49.0 & 2.3 & 7.2 & 1.8 \\
BD & 28.9 & 58.1 & 2.5 & 9.1 & 1.4 \\
\hline
\end{tabular}

Table 3. Enumeration of Total Heterotrophic Bacteria from Tympanotonus fuscatus.

\begin{tabular}{|c|c|c|c|c|c|c|c|c|}
\hline \multirow[t]{2}{*}{ Sampling Site } & \multicolumn{2}{|c|}{ Nutrient Agar Cfu/g } & \multicolumn{2}{|c|}{$\begin{array}{l}\text { Salmonella Shigellar Agar } \\
\text { Cfu/g }\end{array}$} & \multicolumn{2}{|c|}{$\begin{array}{l}\text { Eosine Methylene Blue } \\
\text { Agar Cfu/g }\end{array}$} & \multicolumn{2}{|c|}{ Mineral Salt Agar Cfu/g } \\
\hline & Raw & Boiled & Raw & Boiled & Raw & Boiled & Raw & Boiled \\
\hline Emuoha & $2.11 \times 10^{6}$ & $1.49 \times 10^{6}$ & $4.93 \times 10^{4}$ & $8.35 \times 10^{3}$ & $1.44 \times 10^{4}$ & $8.10 \times 10^{3}$ & $9.95 \times 10^{3}$ & $4.63 \times 10^{3}$ \\
\hline Cawthone Channel & $1.91 \times 10^{6}$ & $9.75 \times 10^{6}$ & $1.10 \times 10^{4}$ & $5.52 \times 10^{3}$ & $1.02 \times 10^{4}$ & $7.88 \times 10^{3}$ & $9.48 \times 10^{3}$ & $4.30 \times 10^{3}$ \\
\hline Okrika & $1.85 \times 10^{6}$ & $1.20 \times 10^{6}$ & $1.14 \times 10^{4}$ & $2.02 \times 10^{3}$ & $9.33 \times 10^{3}$ & $3.70 \times 10^{3}$ & $5.75 \times 10^{3}$ & $2.90 \times 10^{3}$ \\
\hline Bodo & $2.37 \times 10^{6}$ & $1.41 \times 10^{6}$ & $1.01 \times 10^{4}$ & $2.38 \times 10^{5}$ & $7.53 \times 10^{3}$ & $5.08 \times 10^{3}$ & $6.13 \times 10^{3}$ & $3.68 \times 10^{3}$ \\
\hline
\end{tabular}




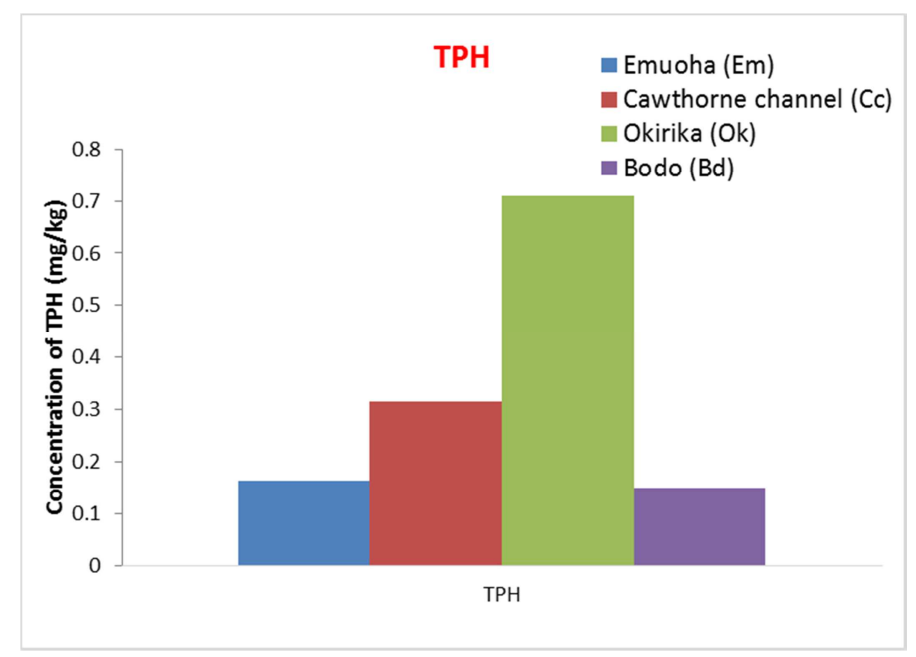

Figure 1. Total Petroleum Hydrocarbon content of samples from various sites.

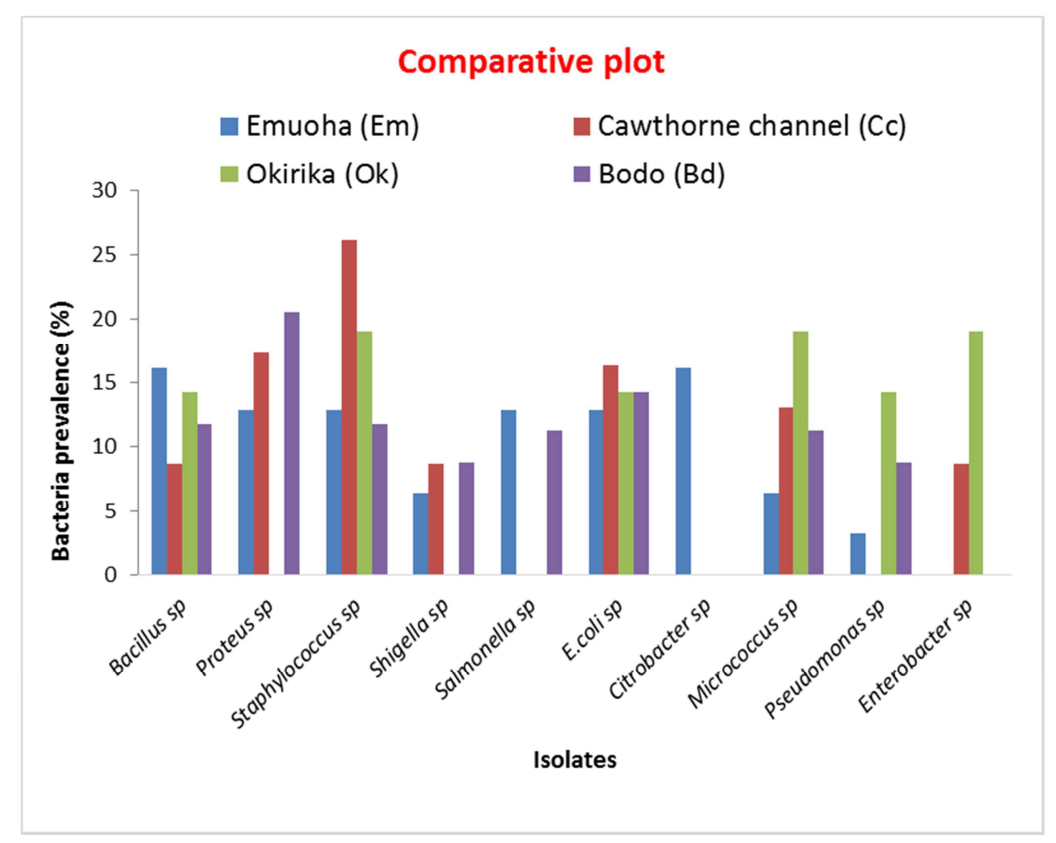

Figure 2. Prevalence of bacteria isolates at sample sites.

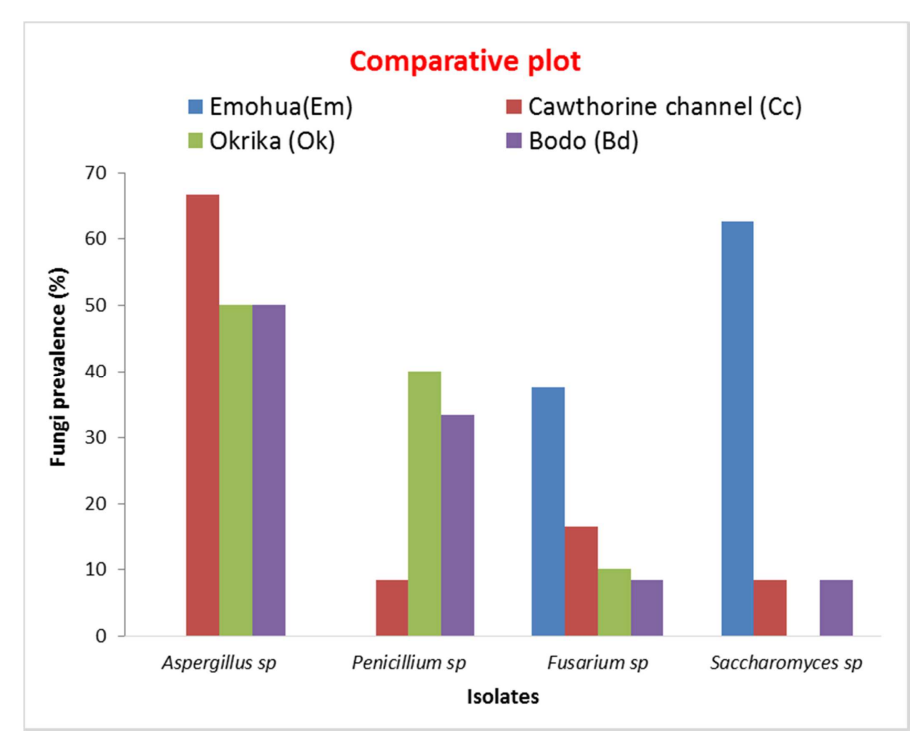

Figure 3. Prevalence of Fungal cultures at sample sites. 
Table 4. Mean Total Fungal Count.

\begin{tabular}{lllll}
\hline \multirow{2}{*}{ Sample Code } & THF $($ PDA) & & HUF $($ MSA) & \\
\cline { 2 - 5 } & Raw $(\mathbf{c f u} / \mathbf{g}) \times \mathbf{1 0}^{\mathbf{3}}$ & Boiled $(\mathbf{c f u} / \mathbf{g}) \times \mathbf{1 0}^{\mathbf{3}}$ & Raw $(\mathbf{c f u} / \mathbf{g}) \times \mathbf{1 0}^{\mathbf{3}}$ & ${\text { Boiled }(\mathbf{c f u} / \mathbf{g}) \times \mathbf{1 0}^{\mathbf{3}}}$ \\
\hline Emohua & 2.68 & 1.90 & 3.30 & 1.98 \\
Cawthorne Channel & 2.10 & 1.42 & 2.08 & 1.28 \\
Okrika & 2.05 & 1.55 & 2.70 & 1.53 \\
Bodo & 3.88 & 2.00 & 2.68 & 1.85 \\
\hline
\end{tabular}

\section{Discussion}

Periwinkle (Tympanotonus fuscatus) samples harvested from crude oil and non-crude oil contaminated areas were assessed using different methods to determine their physiochemical and microbiological quality .

The result on the concentration of heavy metals in periwinkle samples harvested from non-crude oil contaminated soil are in the order $\mathrm{Fe}>\mathrm{Zn}>\mathrm{Mn}>\mathrm{Cu}>\mathrm{Cr}>\mathrm{Ni}>\mathrm{Cd}>\mathrm{Pb}$. The values for $\mathrm{Fe}, \mathrm{Zn}$ and $\mathrm{Cu}$ were higher than the WHO/FAO 2011 standard, hence an urgent need to monitor sources of periwinkles sold in the market. The increase in Zinc and Fe, agrees with the works of [10-12]. Heavy metals such as Fe, $\mathrm{Zn}, \mathrm{Mn}$ found in periwinkles could be metalloenzymes, which are important in metabolic activities of the periwinkles. [13-15] also reported an increase in heavy metal concentration in periwinkles and crab. The result obtained on the proximate analysis of periwinkle samples from crude oil and non-crude oil contaminated areas showed that periwinkles contain some amount of protein, moisture, fiber, ash, lipid and carbohydrate. This result is in agreement with the previously reported work by [16] that periwinkle is rich in protein, mineral, vitamins, carbohydrates which is stored as glycogen.

The microbiological analysis of periwinkle showed high microbial load, however, the count was higher in Raw samples when compared to the Boiled samples, this work corroborates with previously reported work by [16] that periwinkles from Ishiet and Oron had high microbial load. The statistical analysis on their data also showed that their microbial load was above the acceptable limit stipulated by the International Commission on Microbiological Specifications for Food (ICMSF) which state that the maximum microbial count in shell fishes should not exceed the acceptable limit of $1 \times 10^{5} \mathrm{cfu} / \mathrm{g}$ for the safety of the consumers. The result of the Boiled periwinkle samples showed that boiling of periwinkle will help to drastically reduce the microbial load on shell fishes (periwinkle).

The result also showed that microorganisms are able to survive in the contaminated and non-contaminated environment (aquatic) no matter the level of pollution and shell fishes like periwinkle are capable of harboring the accumulating pathogenic and hydrocarbon utilizing microorganisms, this collaborates with the previous work by [17] that shell fishes are able to harbor and bio magnify microorganism in their environment. The organisms isolated and identified in this study include: Bacillus sp, Proteus sp, Staphylococcus sp, Shigella sp, Salmonella sp, E. coli, Citrobacter sp, Micrococcus sp, Pseudomonas sp,
Enterobacter sp, Aspergillus sp, Fusarium sp, Penicillium sp and Saccharomyces sp in both Raw and Boiled samples from crude oil and non-crude oil contaminated areas and is an indication that the water is contaminated with enteric and indicator organisms which could be as a result of bathing, defecating by the local populace and disposal of wastes into the river. The organisms isolated agreed with the previous reported works by [18-20] that marine products are usually contaminated by microorganisms which originated from contaminants present in the aquatic environment.

The Pathogenic organisms isolated are of health concern, they are implicated to causing health problems like infantile diarrhea and meningitis caused by $E$. coli, cerebrospinal fluid shunts in children caused by Staphylococcus sp, Salmonellosis (food poisoning) caused by Salmonella sp, acute gastroenteritis and bacteremia in persons with underlying hematological malignancies or hepatic dysfunctions caused by Micrococcus sp and Bacillus sp and infections of wounds, burns and blood caused by Pseudomonas sp. The isolation of Pseudomonas in the study indicates that persons with open or untreated wounds with other blood infections bath in the water bodies. The presence of Aspergillus sp, Fusarium sp, Penicillium sp and Saccharomyces $\mathrm{sp}$ in both crude oil and non-crude oil contaminated areas implicates that these fungi are capable of growing under all conditions and can be useful for the remediation of the polluted environment.

\section{Conclusion}

This study revealed that periwinkle (Tympanotomus fuscatus) samples from both crude oil contaminated and noncontaminated swamp though is a cheap source of protein, harbored pathogenic organisms and heavy metals, some of the metals exceeded the FAO/FEPA 2003 and FAO/WHO 2011 standards and could have toxic effect on the health hence; the need for urgent monitoring of the source of periwinkles harvested and sold. The pathogenic microorganisms harbored by periwinkle pose great concern to human health hence; periwinkles are not safe for human consumption if not properly boiled. It is advised that periwinkles should be properly washed and cooked before consumption in order to avoid diseases, therefore, it should be given adequate safety attention and awareness should be created to consumers.

\section{Disclosure}

There is no competing interest. 


\section{Acknowledgements}

We thank our colleagues from the University of Port Harcourt who provided insight and expertise to this research

\section{References}

[1] Cram S, Siebe C, Ortíz-Salinas R, Herre A. Mobility and Persistence of petroleum hydrocarbons in peat soils of South Eastern Mexico. Soil Sed. Contaminat. 2004; 13 (5), 341-360.

[2] Obire O, Anyanwu EC. Impact of various concentrations of crude oil on fungal populations of soil. Int J Environ Sci Technol. 2009; 6: 211-218.

[3] Villeneuve DS, Khim J, Kannan KP Giesy J. Relative Potencies of Individual Polycyclic Aromatic Hydrocarbons to Induce Dioxin-like and Estrogenic Responses in Three Different Cell Lines. Environmental toxicology. 2002; 17: 128-37. 10.1002/tox.10041.

[4] Ikenaka Y, Eun H, Watanabe E, Miyabara Y. Sources, Distribution, and Inflow Pattern of Dioxins in the Bottom Sediment of Lake Suwa, Japan. Bulletin of environmental contamination and toxicology. 2005; $75.915-21$. 10.1007/s00128-005-0837-2.

[5] Oronsaye CG. The effect of transplantation experiment on the shell morph of the shell fish Tympanotonus fuscatus Tropical Ecology 2002; 43 (2): 351-354.

[6] Odiete WO. Environmental Physiology of Animals and Pollution, 1st ed. Diversified Resources Limited, 1999; Lagos.1-end.

[7] Frazier WC, Westhoff DC. Spoilage of fish and other seafoods 1988: In Food Microbiology, 4th Edition. McGRaw-Hill Book company, Singapore. 1988; Pp.e45 243-253.

[8] FAO/WHO Joint food standards program committee on contaminants in food, 2011. $5^{\text {th }}$ Edition.

[9] Federal Environmental Protection Agency (FEPA). Guidelines and standards for environmental pollution Nigeria. 2003; 237240.33 .

[10] Miebaka M, Ekweozor IKE, Nsirim DN. Assessment of heavy metals and bioaccumulation in Periwinkle (Tympanotonus fuscatus $\mathrm{Vr}$ radula (L) obtained from upper reaches of the
Bonny Estuary, Nigeria Journal of heavy metal toxicity and diseases. 2017; 2: 2-3.

[11] Ikejimbah, CC, Sakpa SS. Comparartive study of some heavy metals concentration in water and Tympanotonus fuscatus var radula samples of Egbokodo River, Warri, Nigeria. Inter. J. of Modern Bio. 2014; 2: 7-15.

[12] Ijeomah H, Edet DK, Oruh E, Ijeomah A. Assessment of Heavy Metals in Tissues of Selected Non-Vertebrate Wildlife Species in Oil Polluted Sites of Delta State, Nigeria. 10.5251/abjna. 2015; 6.2.63.73.

[13] Oluowo EF and Olomukoro, JO. Heavy Metal Bioaccumulation in periwinkles (Tympatonus fuscatus) and Blue crab (Callinestes amnicola) harvested from perturbed tropical mangrove forest in Niger Delta, Nigeria. Journal of Agriculture and ecological research international 2017; 11 (1): 1-12.

[14] Ayenimo JG, Adeeyinwo CE, Amoo IA. Heavy metal pollutants in Warri river, Nigeria. Kragujevac J. sci. 2005; 27:43-50.

[15] Ololade AI, Lajide LA, Oladoja NA. Investigation of heavy metals of edible marine sea food. African Journal of pure Chemistry. 2008; 2 (12): 121-1.

[16] Bukola CA, Abiodun AO, Adeniyi AO, Damilola OA. Bacateriology and proximate Analysis of Periwinkle from two Different Creeks in Nigeria. World Applied Sciences Journal, 2006; 1 (2) 87-91.

[17] Davies OA, Allison ME, Uyi HS. Bioaccumulation of heavy metals in water Tympanotonus fuscatus varradula) from the Elechi creek, Niger Delta. African Journal of Biotechnology. 2006; 6: 968-973.

[18] Nrior RR, Iyibo SN, Ngerebara NN. Microbiological assessment of Niger Delta shell sea foods: Periwinke (Tympanotonus Fuscatus), Oyster and veined Rapa Whelk (Rapa na venosa) from crude oil polluted site. Int. J. of current research in multidisciplinary: 2017; 2 (7): 1-9.

[19] Adebayo-Tayo BC, Abiodun AO, Etuk FI. Studies on microbiological proximate microbial and Heavy metal composition of fresh water snails from Niger Delta Creek in Nigeria. AU. J. T. 2011; 14 (4) 290-298.

[20] Jay MJ. Modern Food Microbiology 6 An Aspen Publication, 2006. 